$1-1-1916$

\title{
Amount and Cost of Labor Required for Growing Crops in West Virginia
}

\author{
O. M.Johnson
}

A. J. Dadisman

Follow this and additional works at: https://researchrepository.wvu.edu/ wv_agricultural_and_forestry_experiment_station_bulletins

\section{Digital Commons Citation}

Johnson, O. M. and Dadisman, A. J., "Amount and Cost of Labor Required for Growing Crops in West Virginia" (1916). West Virginia Agricultural and Forestry Experiment Station Bulletins. 163.

https://researchrepository.wvu.edu/wv_agricultural_and_forestry_experiment_station_bulletins/163 



\section{9sest Hirginia afnibersity Aqricultural Experiment Station}

MORGANTOWN

DEPARTMENT OF FARM MANAGEMENT

\section{Amount and Cost $_{i=}^{-}$of Labor Required for Growing Crops in West Virginia}

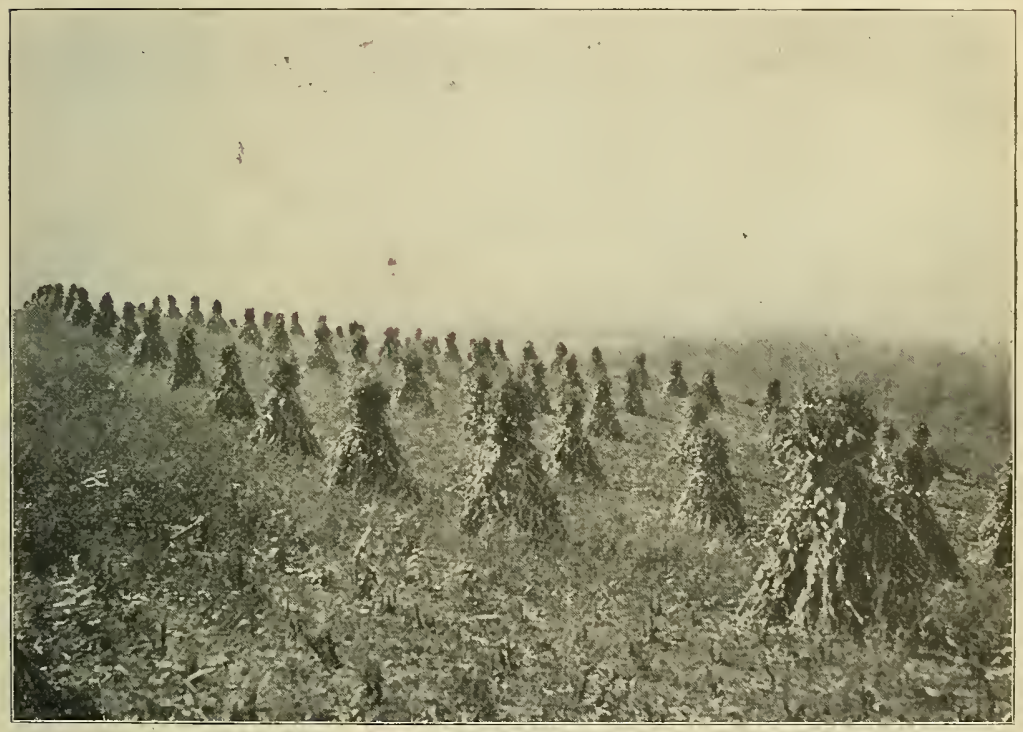

BY

O. M. Johnson and A. J. Dadisman

In Co-operation with the Office of Farm Management, United States Department of Agriculture

Bulletins and Reports of this Station will be mailed free to any citizen of West Virginia upon written application. Address Director of the West Virginia Agricultural Experiment Station, Morgantown, W. Va. 


\section{THE STATE OF WEST VIRGINIA}

\section{Educational Institutions}

\section{THE STATE BOARD OF CONTROL}

JAMES S. LAKIN, President.

A. BLISS MCCRUM.

Charleston, W. Va.

J. M. WILLIAMSON.

Charleston, W. Va.

Charleston, W. Va.

The State Board of Control has the direction of the financial and business affairs of the state educational institutions.

\section{THE STATE BOARD OF REGENTS}

M. P. SHAWKEY, President...........................................Charleston, W. Va. State Superintendent of Schools

GEORGE S. LAIDLEY

Charleston, W. Va.

ARLEN G. SWIGER

Sistersville, W. Va.

EARL W. OGLEBAY.

Wheeling, W. Va.

JOSEPH M. MURPHY

Parkersburg, W. Va.

The State Board of Regents has charge of all matters of a purely scholastic nature concerning the state educational institutions.

\section{West Virginia University}

FRANK BUTLER TROTTER, LL.D.

President

\section{AGRICULTURAL EXPERIMENT STATION STAFF}

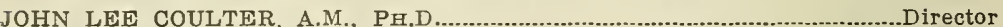

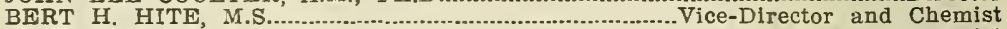
W. E. RUMSEY, B.S. Agr.................................................................. State Entomologist

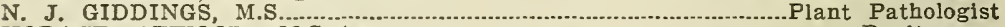

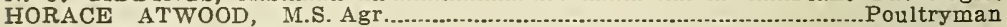

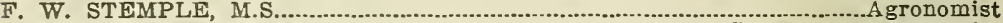

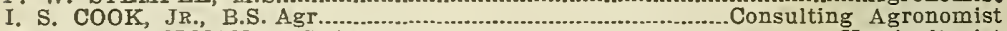
W H ALDERMAN, B.S. Agr......................................................... Horticulturist L. M. PEAIRS, M.S................................................................. Research Entomologist

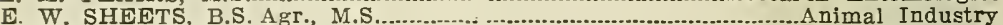

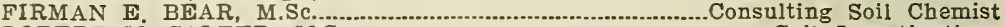

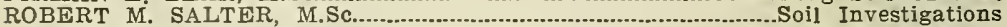

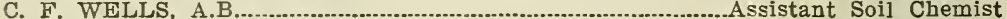
C. A. LUEDER, D.V.M. $\dagger$ L. I. KNIGHT, PH.D. A. L. DACY, B.Sc.... Veterinary Science Plant Physiologist FRANK B. KUNST, A.B CHARLES E. WEAKLEY, JR J. H. BERGHIUS-KRAK, B.Sc GEORGE W. BURKE, B.S. ANTHONY BERG, B.S.

E. C. AUCHTER, B.S. Agr. iate Horticulturist Assistant Chemist Assistant Chemist .Assistant Chemist Assistant Chemist L. F. SUTTON, B.S., B.S. Agr.................................................. Assistant Horticulturist H. L. CRANE, B.S. Agr..............................................................sssistant Horticulturist W. B. KEMP, B.S. Agr...

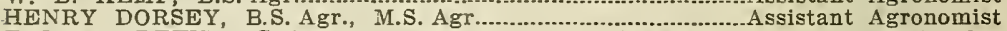
E. L. ANDREWS, B.S. Agr..................................................... in Poultry Husbandry

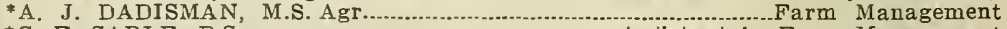
*C. F. SARLE, B.S....................................................ssistant in Farm Management

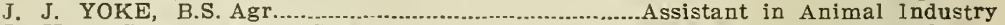
R. H. TUCKWILLER, B.S. Agr.....................................ssistant in Animal industry

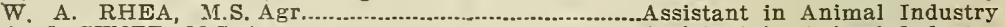
A. J. SWIFT, M.S. Agr. *C. H. SCHERFFIUS

A. B. BROOKS, B.S. Agr. Assistant in Animal Industry

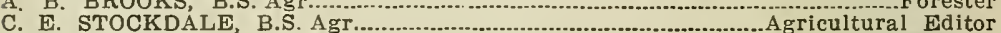
W. J. WHITE. 


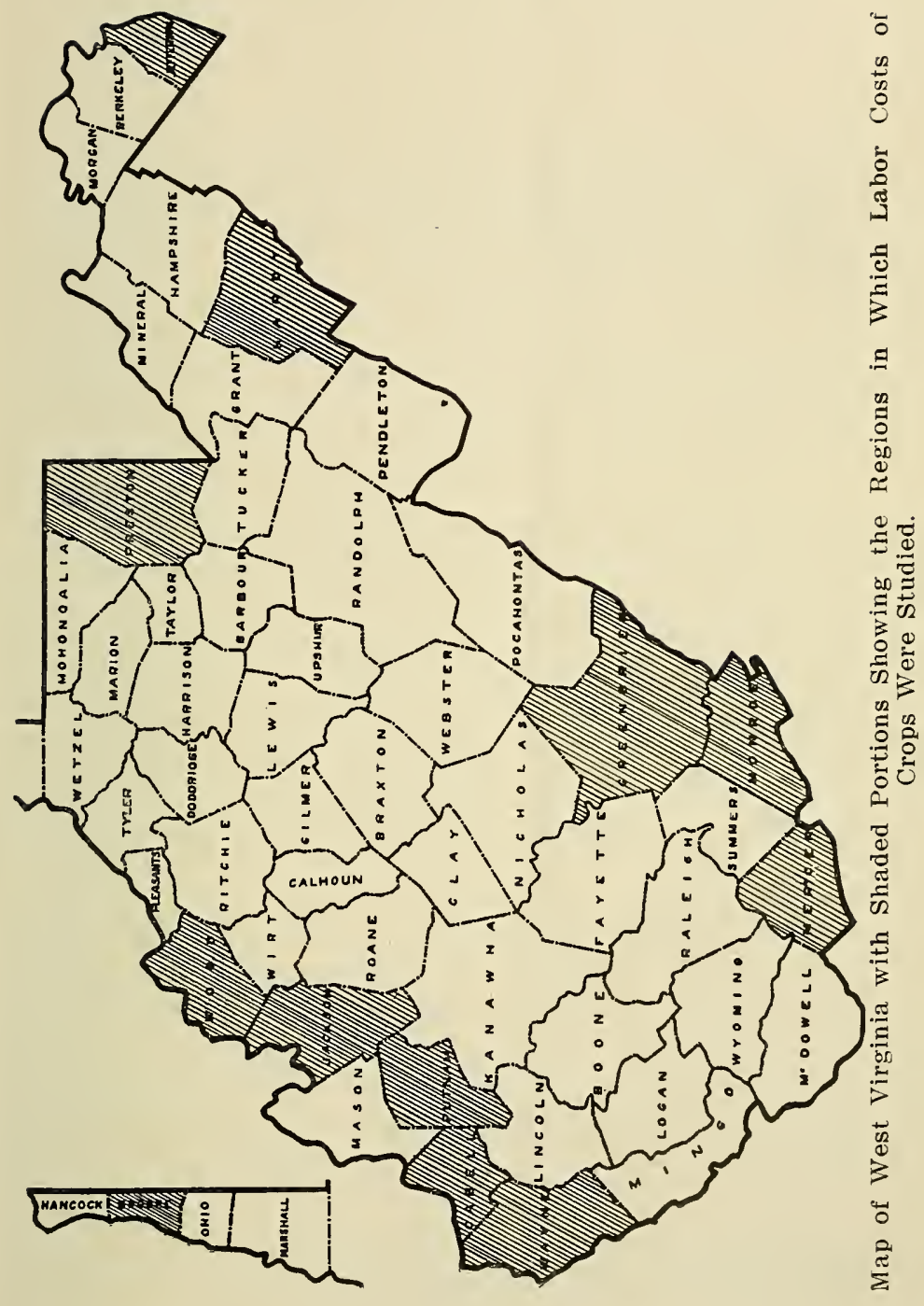




\section{SUMMARY.}

[Facts regarding the amount and cost of man and horse labor required for growing various crops in West Virginia, compiled from data presented in this bulletin. Man labor is valued at 15 cents per hour, horse labor at 10 cents per hour, for ten-hour days].

1. To grow and harvest an acre of corn (yield, 40.4 bushels) required an average of 5.71 man days and 4.29 horse days at a total cost of $\$ 12.86$.

2. To grow and harvest an acre of wheat (yield, 18.4 bushels) required an average of 2.31 man days and 3.36 horse days at a total cost of $\$ 6.83$.

3. To grow and harvest an acre of oats (yield, 31.6 bushels) required an average of 2.29 man days and 2.84 horse days at a total cost of $\$ 6.28$.

4. To harvest an acre of hay (yield, 1.27 tons) required an average of .81 man day and .71 horse day at a total cost of $\$ 1.91$.

5. To grow and harvest an acre of potatoes (yield, 154.6 bushels) required an average of 10.17 man days and 8.24 horse days at a total cost of $\$ 23.49$.

6. To grow and harvest an acre of buckwheat (yield, 24.8 bushels) required an average of 2.91 man days and 2.98 horse days at a total cost of $\$ 7.34$.

7. To grow and harvest an acre of tobacco (yield, 985 pounds) required an average of 37.76 man days and 5.31 horse days at a total cost of $\$ 61.95$. 


\title{
Amount and Cost of Labor Required for Growing Crops in West Virginia.
}

\author{
By O. M. JOHNSON and A. J. DADISMAN.
}

\section{INTRODUCTION.}

The farmer seldom considers the whole cost of producing a field crop. The direct cash outlay is more noticeable than the labor cost, which is generally much greater than all other costs combined, but is commonly lost sight of in figuring profits. The amount of labor necessary to produce a field crop varies greatly. It requires much more labor to fit some soils for crops than it does others; some farmers put more labor on their fields than others do whether it is economical or not; and it requires more labor to produce crops some years than it does others.

Whenever it is desirable to estimate the total cost of crop production, the following charges must be added to those given for labor of man and horse? rent of land, use of machinery, cost of seed, cost of fertilizer, charge for storage room, and interest on money invested in the crop before it is marketed.

During the summers of 1913, 1914, and 1915 crop management data were obtained by visiting farmers in twelve counties in different parts of West Virginia. From fifteen to thirty records on each crop were taken in each county, from which averages have been made.

The value of man labor as here used is 15 cents per hour and of horse lahor 10 cents per hour, while the length of a work day is 10 hours.

Size of farm, soil, and climatic conditions vary greatly in the whole region but not so much in the given groups. All the records were obtained from farms where the fields were large enough to show average conditions. While crop yields vary considerably, the amount of labor required to produce a crop does not vary greatly with different yields.

\section{AMOUNT AND COST OF MAN AND HORSE LABOR REQUIRED TO GROW AN ACRE OF CORN.}

Since corn for grain and silage is one of the chief crops of the whole state, more complete records were obtained for this crop than for any other. 


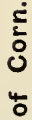

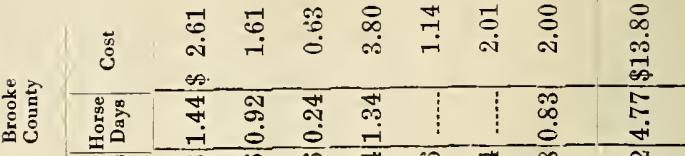

4

$\frac{\square}{4}$

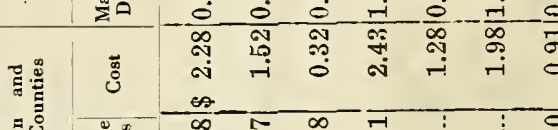

ส

造总

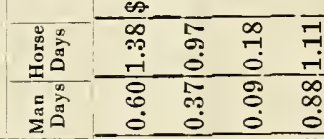

$\frac{3}{3}$

$+$

ठ

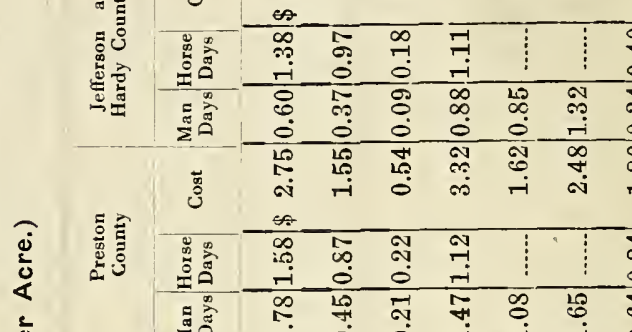

.

3

㻤

a

$\frac{0}{0}$

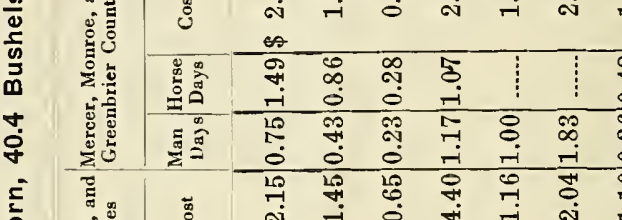

๑

은

I

$\frac{\pi}{\frac{1}{5}}$

$\sum \frac{\pi}{2}$

ठ

范

$\frac{\text { T }}{\pi}$

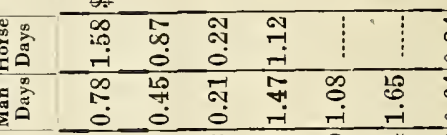

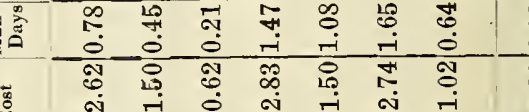

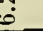

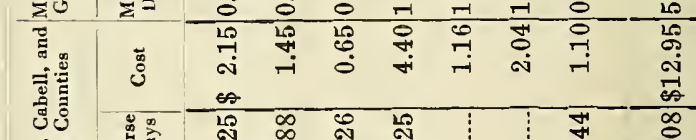

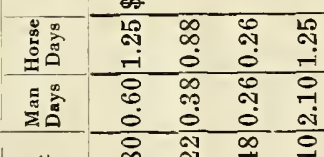

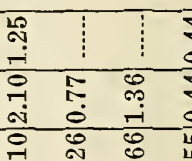

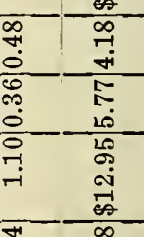

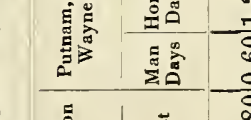

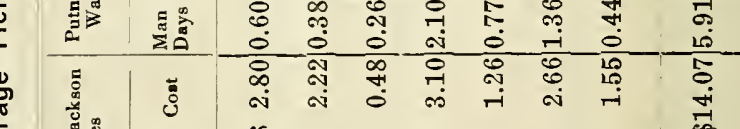

䓂

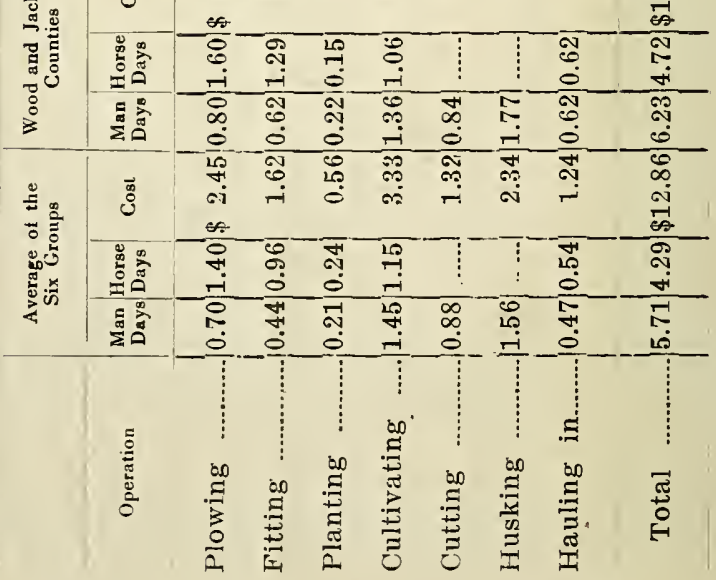


Table I shows that the amount of man labor required to grow an acre of corn in the different regions varied from 6.28 days, the greatest amount, to 4.45 days, the least amount, with an average of 5.71 days. Horse labor varied from 4.77 days, the greatest amount, to 4.04 days, the least amount, with an average of 4.29 days. The cost of labor ranged from $\$ 14.07$ per acre, the highest, to $\$ 10.72$, the lowest, with an average of $\$ 12.86$.

The variation in the cost of each operation in the different sections was not great. The difference between the highest and the lowest cost of plowing an acre in the various regions was 65 cents; of fitting 77 cents; of planting 33 cents; of cultivating $\$ 1.97$; of cutting 48 cents; of husking 76 cents; of hauling in corn $\$ 1.09$; and the difference between the highest and the lowest total cost was $\$ 3.35$.

Man labor on corn for silage is practically the same as on corn for grain, but it requires about one horse day more. To the figures given $\$ 1.00$ may be added for the labor cost of producing silage corn.

\section{AMOUNT AND COST OF MAN AND HORSE LABOR REQUIRED TO GROW AN ACRE OF WHEAT.}

Some wheat is grown in the greater part of the state, but in many sections very little is grown. Complete data on the labor and cost of growing wheat were collected in but three sections.

TABLE II.-Amount and Cost of Man and Horse Labor Required to Grow an Acre of Wheat.

(Average Yield of Wheat, 18.4 Bushels per Acre.)

\begin{tabular}{|c|c|c|c|c|c|c|c|c|c|c|c|c|}
\hline \multirow[b]{2}{*}{ Operation } & \multicolumn{3}{|c|}{$\begin{array}{c}\text { Average of } \\
\text { the } \\
\text { Ibree Groups }\end{array}$} & \multicolumn{3}{|c|}{$\begin{array}{l}\text { Monroe and } \\
\text { Greenbrier } \\
\text { Counties }\end{array}$} & \multicolumn{3}{|c|}{$\begin{array}{l}\text { Preston } \\
\text { County }\end{array}$} & \multicolumn{3}{|c|}{$\begin{array}{c}\text { Jefferson } \\
\text { and } \\
\text { Hardy Counties }\end{array}$} \\
\hline & $\begin{array}{l}\text { Man } \\
\text { Days }\end{array}$ & $\begin{array}{r}\text { Horse } \\
\text { Days }\end{array}$ & Cost & $\underset{\text { Man }}{\text { Days }}$ & $\begin{array}{l}\text { Horse } \\
\text { Days }\end{array}$ & Cost & $\underset{\text { Days }}{\text { Man }} \mathrm{F}$ & $\begin{array}{l}\text { Horse } \\
\text { Days }\end{array}$ & Cost & $\begin{array}{c}\text { Man } \\
\text { Days }\end{array}$ & $\begin{array}{r}\text { Horse } \\
\text { Days }\end{array}$ & Cost \\
\hline Plo & 0.75 & 51.53 & $\$ 2.66$ & 1.00 & $2.00 \mid$ & $\$ 3.50$ & $|0.60|$ & 1.20 & $\$ 2.10$ & 0.64 & 1.40 & $\$ 2.3$ \\
\hline Fitt & 0.42 & 0.92 & 1.55 & 0.46 & 0.82 & 1.51 & 0.49 & 1.18 & 1.92 & 0.30 & 0.76 & 1.2 \\
\hline Seeding & 0.12 & 0.24 & 0.42 & 0.14 & 0.28 & 0.49 & 0.11 & 0.22 & 0.38 & 0.11 & 0.22 & 0.3 \\
\hline $\begin{array}{l}\text { Cutting and } \\
\text { shocking }\end{array}$ & 0.34 & \pm 0.34 & 0.85 & 0.36 & 0.35 & 0.89 & & 0.33 & 0.82 & & 34 & 0.8 \\
\hline Hauling & 0.32 & 0.31 & 0.79 & 0.27 & 0.24 & 0.64 & 0.33 & 0.33 & 0.82 & 0.35 & 0.36 & 0.8 \\
\hline Threshing & 0.36 & 60.02 & 0.56 & 0.57 & $\mid \ldots . .$. & 0.86 & $|0.30|$ & $|\ldots \ldots|$ & 0.45 & 0.20 & $|0.05|$ & 0.35 \\
\hline Total & 2.31 & $1|3.36|$ & $\$ 6.83$ & $|2.80|$ & $|3.69|$ & $\$ 7.89$ & $\mid 2.16$ & $3.26 \mid$ & $\$ 6.49$ & 1.94 & 3.13 & $\$ 6.03$ \\
\hline
\end{tabular}


Table II shows that the amount of man labor required to grow an acre of wheat in the different regions varied from 2.8 days, the greatest amount, to 1.94 days; the least amount, with an average of 2.31 days. Horse labor varied from 3.69 days, the greatest amount, to 3.13 days, the least amount, with an average of 3.36 days. The cost of labor ranged from $\$ 7.89$. the highest, to $\$ 6.03$, the lowest, with an average of $\$ 6.83$.

The cost of plowing varied from $\$ 3.50$ per acre to $\$ 2.10$; the cost of threshing varied from 86 cents to 35 cents. The cost of other operations varied but little.

\section{AMOUNT AND COST OF MAN AND HORSE LABOR REQUIRED TO GROW AN ACRE OF OATS.}

Oats is grown throughout the state, but in many sections it is grown in small quantities and is frequently fed in the sheaf or as oat hay. Complete data on the labor and cost of growing oats were collected in but two sections. TABLE III.-Amount and Cost of Man and Horse Labor Required to
Grow an Acre of Oats.

(Average Yield of Oats, 31.6 Bushels per Acre.)

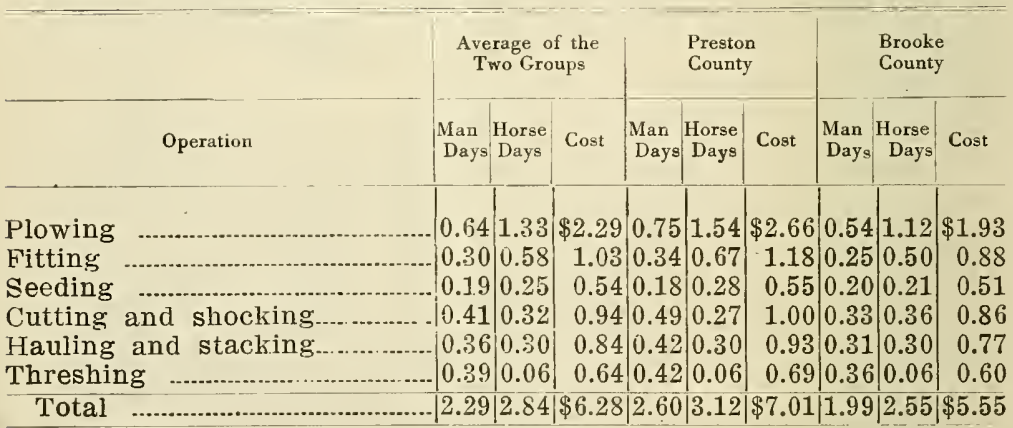

The average of the two regions given in Table III shows that it required 2.29 man days and 2.84 horse days to grow an acre of oats, and that the average cost was $\$ 6.28$. The cost of each operation was slightly higher in Preston County than it was in Brooke County. When the oats is used for hay or fed in the sheaf the cost of production is somewhat less. 


\section{AMOUNT AND COST OF MAN AND HORSE} LABOR REQUIRED TO AN ACRE OF HAY. RALVEST

The labor on hay includes cutting, shocking, hauling, and stacking, but does not include seeding.

TABLE IV.-Amount and Cost of Man and Horse Labor (Cutting, Hauling, and Stacking) Required to Harvest an Acre of Hay. (Average Yield of Hay, 1.27 Tons per Acre.)

\begin{tabular}{|c|c|c|c|}
\hline & Man & Horse & \\
\hline & Days & Days & Cost \\
\hline Average of the five groups.. & 0.81 & 0.71 & $\$ 1.91$ \\
\hline Wood and Jackson counties.......... & 0.66 & 0.76 & 1.75 \\
\hline $\begin{array}{l}\text { Mercer, Monroe, and Greenbrier } \\
\text { counties }\end{array}$ & 0.81 & 0.63 & 1.84 \\
\hline Preston County & 0.72 & 0.78 & 1.86 \\
\hline Jefferson and Hardy counties................ & 1.06 & 0.78 & 2.37 \\
\hline Brooke County & 0.70 & 0.60 & 1.65 \\
\hline
\end{tabular}

Table IV shows that the amount of man labor required to harvest an acre of hay varied from 1.06 days, the greatest amount, to 0.66 day, the least amount, with an average of 0.81 day. Horse labor varied from 0.78 day, the greatest amount, to 0.60 day, the least amount, with an average of 0.71 day. The cost of labor ranged from $\$ 2.37$, the highest, to $\$ 1.65$, the lowest, with an average of $\$ 1.91$.

\section{AMOUNT AND COST OF MAN AND HORSE LABOR REOUIRED TO GROW AN ACRE OF POTATOES.}

Potatoes are grown in small quantities for home use throughout the state and in commercial quantities in but a few sections. Complete data on the labor and cost of growing potatoes were collected in but one section.

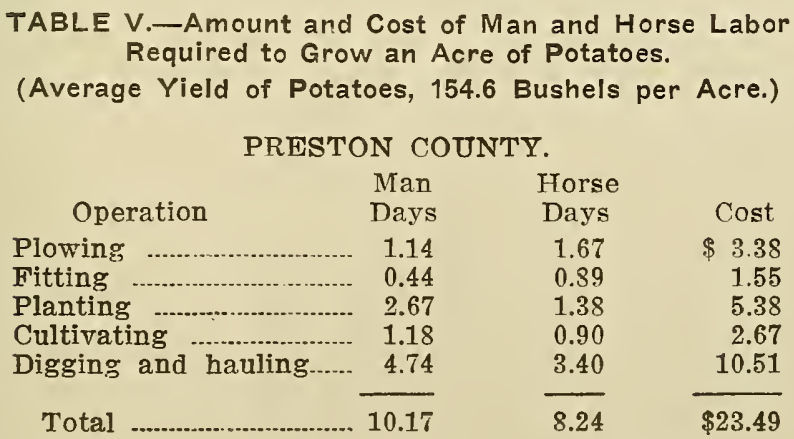


Table $\mathrm{V}$ shows the amount of man labor required to grow an acre of potatoeseto be 10.17 days, horse labor to be 8.24 days, and cost to be $\$ 23.49$. Many men do not plow nor fit ground for potatoes; the plowing and fitting are included in planting. As the ground, usually sod, is plowed the potatoes are planted in every third or fourth furrow and covered when plowing the next one. The use of this method reduces the cost \$4.93, making the total cost $\$ 18.56$.

\section{AMOUNT AND COST OF MAN AND HORSE LABOR REQUIRED TO GROW AN ACRE OF BUCKWHEAT.}

Preston County produces about one-third of the buckwheat produced in the state. The crop is of minor importance in most other counties.

TABLE VI.-Amount and Cost of Man and Horse Labor Required to Grow an Acre of Buckwheat.

(Average Yield of Buckwheat, 24.8 Bushels per Acre.)

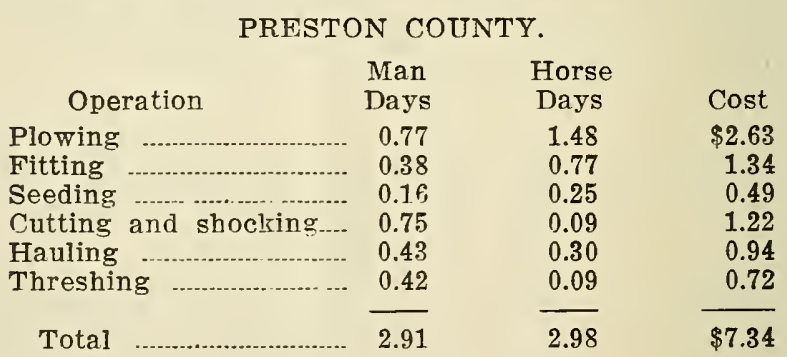

Table VI shows that it required 2.91 man days and 2.98 horse days, at a cost of $\$ 7.34$, to grow an acre of buckwheat. Buckwheat is frequently grown on new land which requires no plowing. When grown in this way the cost is reduced about $\$ 2$ per acre. 


\section{AMOUNT AND COST OF MAN AND HORSE LABOR REQUIRED TO GROW AN ACRE OF TOBACCO.}

Tobacco is grown in only a few counties in the south. western part of the state. Putnam and Cabell counties produce almost one-half of all the tobacco produced in the state

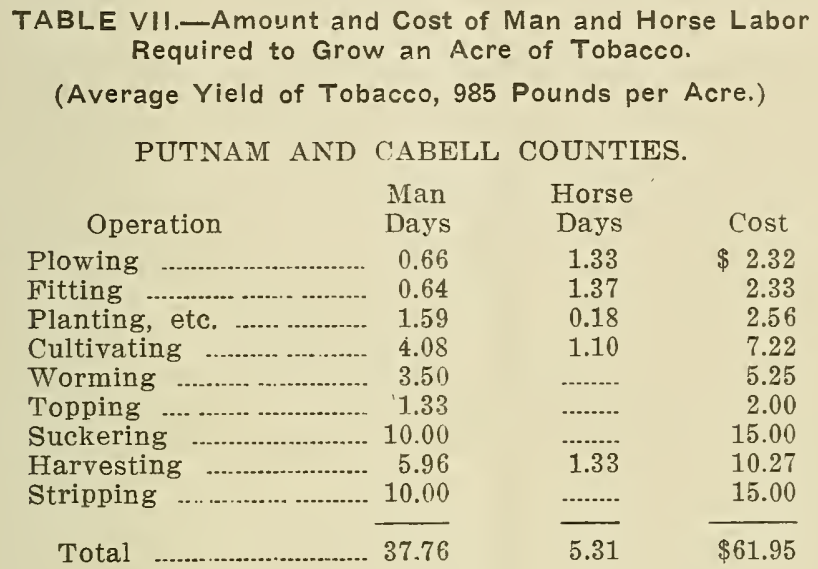

Table VII shows that it required 37.76 man days and 5.31 horse days, at a cost of $\$ 61.95$, to grow an acre of tobacco. 


